\title{
Mineral supplementation of dairy heifers in Marandu-Grass pasture in spring and summer seasons
}

\author{
Suplementação mineral de novilhas leiteiras em pastagens Marandu-Grass nas \\ estações de primavera e verão
}

ALCOFORADO, Carlos Augusto de Almeida Targino ${ }^{1}{ }^{\mathbb{0}}$; LIRA, Aianne Batista ${ }^{1}{ }^{\mathbb{0}}$; SOUZA,

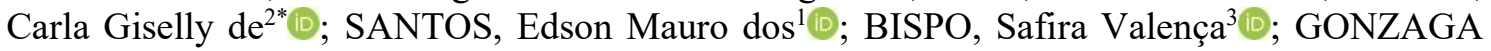
NETO, Severino ${ }^{1}{ }^{\circ}$.

${ }^{1}$ Universidade Federal da Paraíba, Departamento de Produção Animal, Areia - PB - Rodovia BR 079 - Km 12, 58.397-000, Brasil.

${ }^{2}$ Universidade Federal da Grande dourados, Departamento de Zootecnia, João Rosa Góes, 1761

- Vila Progresso, Dourados - MS, 79825-070, Brasil

${ }^{3}$ Universidade Federal Rural de Pernambuco, Departamento de Zootecnia, Av. Bom Pastor, s/n

- Boa Vista, Garanhuns - PE, 55292-270, Brasil

*Endereço para correspondência: carlaxlsouza@yahoo.com.br

\begin{abstract}
Here in this study we assessed dairy heifers kept in tropical grasslands during spring and summer seasons to observe the effects of two supplementation strategies upon their performance. Sixteen dairy heifers (Holstein 5/8 x Gyr 3/4) with $135.25 \mathrm{~kg}$ of body mass were randomly assigned in two supplementation treatments (e.g., mineral salt and protein salt supplement) during spring and summer seasons, divided into two groups of eight animals that represented 4.29 animal unit ha. Initial and final fasted weights (i.e., feed and water withheld for 16h) were obtained before to start and at the end of each grazing cycle (28 days), and then the weight gain $\left(\mathrm{kg}_{\text {animal }}{ }^{-1}\right)$ per grazing cycle was calculated by the difference between final and initial weights. There was no significant effect $(\mathrm{P}<0.05)$ on the intake of dry matter, crude protein, ether extract, neutral detergent fiber, and dry matter digestibility, between treatments $(\mathrm{P}<0.05)$. However, there was a significant effect $(\mathrm{P}<0.05)$ between seasons; e.g., respective means of dry matter intake ( $\mathrm{kg}$ day-1,\% BW g / kg 0.75), intake of crude protein ( $\mathrm{g}$ day-1 g / kg 0.75 ), ether extract ( $g$ day-1), neutral detergent fiber ( $g$ day-1 and $\%$ BW) were 3.95 and $2.88 \mathrm{~kg}, 2.54$ and $1.65 \%, 89.27$ and $59.56 \mathrm{~g} \mathrm{~kg} 0.75,429.89$ and $298.43 \mathrm{~g}$ day-1, 9.72 and $6.18 \mathrm{~g} \mathrm{~kg} 0.75,118.79$ and $84.07 \mathrm{~g} \mathrm{day}^{-1}, 2.90$ and $2.05 \mathrm{~kg} \mathrm{day}^{-1}, 1.86$ and $1.18 \%$, for Spring and Summer seasons. Moreover, the dry matter intake (\% BW and g kg 0.75 of $\mathrm{DM})$ were higher $(\mathrm{P}<0.05)$ during the spring season (e.g., $2.53 \mathrm{vs} 1.64 \% \mathrm{BW}$; and 89.26 vs $59.56 \mathrm{~g} \mathrm{kg0.75} \mathrm{DM).}$
\end{abstract}

Key words: Brachiaria brizantha, growing heifers, rotational grazing.

\section{RESUMO}

Objetivou-se neste trabalho avaliar o desempenho de novilhas leiteiras em recria sob duas estratégias de suplementação mineral. Foram utilizadas 16 novilhas Holandês x 
Zebu com peso vivo médio inicial de $135,25 \mathrm{~kg}$, divididas em 2 tratamentos (sal proteinado e sal mineralizado) e manejadas em pastagem de Brachiaria brizantha cv. Marandu, em sistema rotacionado. Ao final de cada ciclo de 28 dias, os animais foram pesados e o peso utilizado para cálculos de GMD e taxa de lotação. A altura do pasto e a massa de forragem foram mensuradas antes da entrada e após a saída dos animais, onde foram retiradas amostras para análises bromatológicas e estimativas de consumo. Os suplementos foram fornecidos ad libidum. Não houve diferença $(\mathrm{P}>0,05)$ entre os tratamentos, estações e interação tratamento $v$ s estação para o GMD que foram 301,12 e 357,13 g dia-1. Observou-se efeito significativo $(\mathrm{P}<0,05)$ entre as estações (Primavera/Verão). O consumo médio de matéria seca, proteína bruta, extrato etéreo, fibra em detergente neutro foram respectivamente, 3,94 e 2,87 kg; 2,53 e 1,69\%; 89,26 e 59,56 g kg0,75; 429,89 e 238,42 g dia-1; 9,74 e 6,17g kg0,75; 118,79 e 84,07 g dia-1; 2,98 e $2,05 \mathrm{~kg}$ dia-1; 1,86 e 1,17\%, para as estações avaliadas. O consumo de proteinado foi superior $(\mathrm{P}<0,05)$, observando-se 36,50 e $65,50 \mathrm{~g} 100 \mathrm{~kg}-1 \mathrm{PV}$. A digestibilidade da MS foi significativa $(\mathrm{P}<0,05)$ para interação, tratamento vs estação, cujo valores foram respectivamente 49,76 e 46,80 para os tratamentos. Os efeitos dos suplementos utilizados foram equivalentes.

Palavras-chave: Brachiaria Brizantha, recria de novilhas, pastejo rotacionado.

\section{INTRODUCTION}

Livestock farming is one of the principal economic activities in the Northeast region of Brazil. However, there are still many difficulties to attend the nutritional requirements of animals throughout the year (LEITE et al., 2018), thereby negatively affecting the farm income. Running costs of total milk production between 15 and $20 \%$ are expected for the herd replacement (i.e., stocker phase for heifers) in which $50 \%$ of this cost come from animal feeding (COSTA et al., 2007). Nevertheless, this phase is extremely important, once the heifers will be the future cows of the herd (PERES et al. 2015).

Limiting factors during the stocker phase of heifers on pasture-based systems are the availability and quality of forages (FARIAS et al., 2012), is the consequence of low fertility of tropical soils, and long drought periods. For instance, Dias-Filho (2014) estimated that between 50 and $70 \%$ of Brazilian pastures would be in a strong or moderate level of degradation. Then, mineral supplementation is frequently employed as a strategy to improve the productive performance of cattle kept in tropical grasslands (references). Even though the positive effects of mineral supplementation for heifers are well discussed in the literature, the tropical environment has different microclimates and soil features and so further investigations are needed. Here in this study, we assessed dairy heifers kept in tropical grasslands during spring and summer seasons to observe the effects of two supplementation strategies upon their performance.

\section{MATERIAL AND METHODS}

\section{Location}

All procedures involving animals were reviewed and approved by the local committee of animal care and welfare.

\section{Animal Nutrition}


This study was carried out at the dairy milk experimental unit $\left(6^{\circ} 58^{\prime} 12\right.$ 'S latitude, $35^{\circ} 45^{\prime} 15^{\prime} \mathrm{W}$ longitude, and $618 \mathrm{~m}$ of altitude). This region shows an average annual temperature of $23^{\circ} \mathrm{C}$, and rainfall of $1,425 \mathrm{~mm}$, by which is classified as As' type (i.e., hot and humid; Köppen classification), with autumn-winter rains, plus a drought

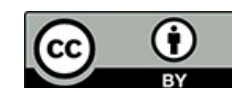

period of five or six months. During the experimental period the meteorological data including Rainfall (Rainf), humidity (Humid) and the average (Tave), maximum (Tmax) and minimum (Tmin) temperatures, were collected from a local weather station (Figure 1).

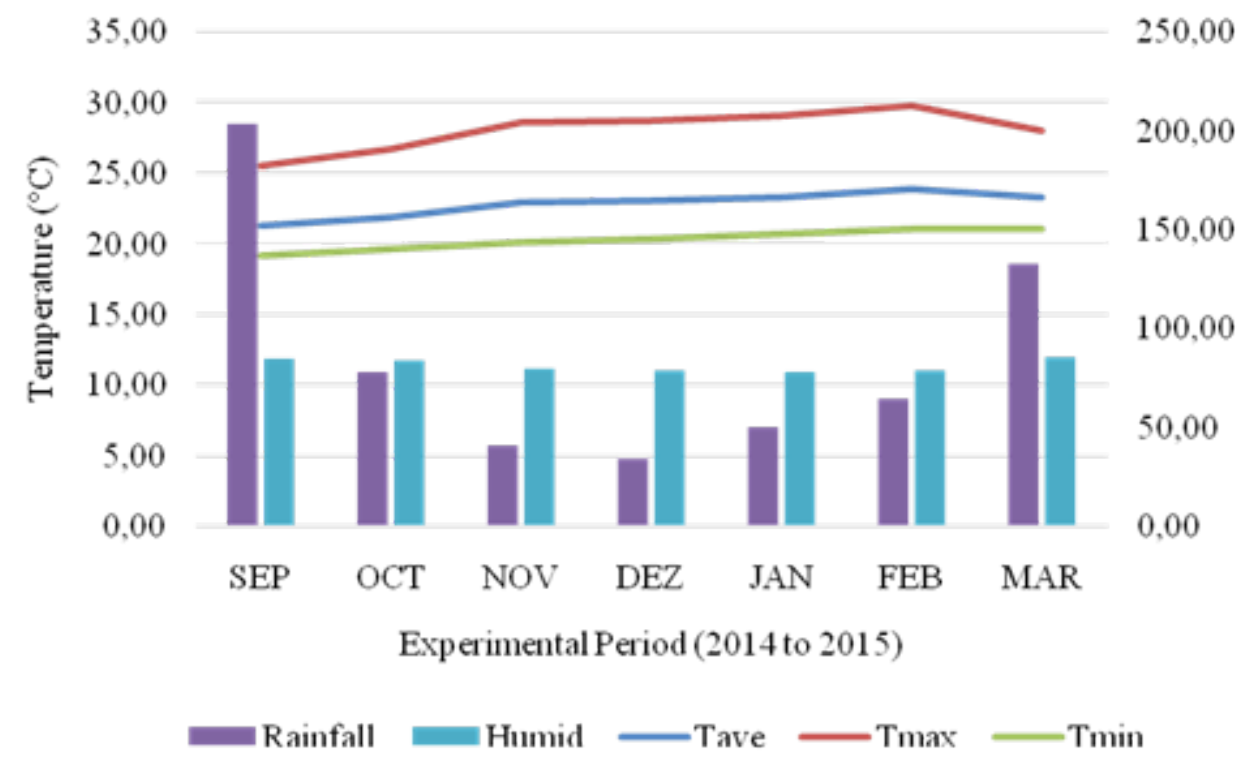

Figure 1. Maximum and minimum temperatures $\left({ }^{\circ} \mathrm{C}\right)$, relative humidity $(\%)$, and rainfall (mm) across the study period (i.e., September 2014 to March 2015).

Animals, experimental design, and management of the experimental area.

Sixteen dairy heifers (Holstein 5/8 x Gyr 3/4) with $135.25 \mathrm{~kg}$ of body weight were randomly assigned in two supplementation treatments (e.g., mineral salt and protein salt supplement; Table 1) during spring and summer seasons (i.e., factorial arrangement $2 \times 2$ ), divided into two groups of eight animals that represented 4.29 animal unit ha-1. The experimental area consisted of 28 paddocks of $400 \mathrm{~m} 2$ (totaling $1.2 \mathrm{ha}$ ) of Brachiaria brizantha $\mathrm{cv}$. Marandu grass with natural shading available, ad libitum water, and supplement trough with space of $45 \mathrm{~cm}$ animal $^{-1}$.

\section{Animal Nutrition}


Table 1. Mineral supplements levels

\begin{tabular}{lccc}
\hline Mineral Element & Mineral salt & Protein salt & Unit \\
\hline Crude protein (Min) & - & 350 & $\mathrm{~g} \mathrm{~g}^{-1}$ \\
N.N.P Equiv. protein (Max) & - & 281 & $\mathrm{~g} \mathrm{~g}^{-1}$ \\
Calcium (Min) & 120 & 40 & $\mathrm{~g} \mathrm{~kg}^{-1}$ \\
Calcium (Max) & 160 & 60 & $\mathrm{~g} \mathrm{~kg}^{-1}$ \\
Phosphorus (Min) & 65 & 20,25 & $\mathrm{~g} \mathrm{~kg}^{-1}$ \\
Sulfur & 19 & 13,9 & $\mathrm{~g} \mathrm{~kg}^{-1}$ \\
Magnesium & 7 & 5 & $\mathrm{~g} \mathrm{~kg}^{-1}$ \\
Sodium & 155 & 97,5 & $\mathrm{~g} \mathrm{~kg}^{-1}$ \\
Cobalt & 120 & 60 & $\mathrm{mg} \mathrm{kg}^{-1}$ \\
Zinc & 4048 & 1446 & $\mathrm{mg} \mathrm{kg}^{-1}$ \\
Cooper & 1000 & 450 & $\mathrm{mg} \mathrm{kg}^{-1}$ \\
Selenium & 13,5 & 9 & $\mathrm{mg} \mathrm{kg}^{-1}$ \\
Manganese & 1138 & 420 & $\mathrm{mg} \mathrm{kg}^{-1}$ \\
Iodine & 62 & 62 & $\mathrm{mg} \mathrm{kg}^{-1}$ \\
Iron & 1200 & 750 & $\mathrm{mg} \mathrm{kg}^{-1}$ \\
Fluor (max) & 650 & 200 & $\mathrm{mg} \mathrm{kg}^{-1}$ \\
\hline Source Rum
\end{tabular}

Source: Rumisal/ NUTRAN- Industry and Commerce Animal Nutrition Ltda.

The heifers were kept under rotational stock with two continuous days of grazing, totalizing twenty-eight days of grazing cycle. We evaluated six grazing cycles between September 2014 and March 2015 (e.g., Spring season: from $19 / 09 / 2014$ to $13 / 10 / 2014$; from $14 / 10 / 2014$ to $10 / 11 / 2014$; from $11 / 11 / 2014$ to $08 / 12 / 2014$; Summer season: from $09 / 12 / 2014$ to $05 / 01 / 2015$; from $06 / 01 / 2015$ to $02 / 02 / 2015$; from $03 / 02 / 2015$ to $02 / 03 / 2015$ ). The Nitrogen was applied at the end of each grazing cycle; i.e., $2 \mathrm{~kg}$ of urea per paddock, by which was equivalent to $300 \mathrm{~kg}$ of N ha-1 year-1 as suggested by Da Silva (2012). The paddocks were subjected to an adaptation grazing period. Moreover, during drought periods we employed irrigation during one hour twice a week (i.e., equivalent to $50 \mathrm{~mm}$ monthly).

\section{Pasture measurements}

The grass biomass was determined before the animals to enter the paddock. The analyzes were carried out to determine the dry matter. Mixed samples of grass from each grazing cycle were collected to determine levels of crude protein (991.20- AOAC, 1995), ether extract (INCT-CA G-004/1 ), neutral detergent fiber (INCT-CA F002/1), indigestible neutral detergent fiber (NDFi), ashes (942.05-AOAC, 1990). Furthermore, the total (Pregrazing) Dry Biomass Grass (DBGt) and residue (post-grazing) (DBGr), intake of dry biomass grass (DBGi) and the daily rate of grass accumulated were determined. The estimation of the potentially digestible pasture dry matter was performed as described by Paulino et al. (2008): DMpd $=0.98$ (100 -\% $\mathrm{NDF})+(\% \mathrm{DNF} \quad-\%$ NDFi$)$, where DMpd is the potentially digestible dry matter, FDN is neutral detergent fiber and NDFi is indigestible neutral detergent fiber.

\section{Animal Nutrition}




\section{hetp://x.doi.org/10.1590/S1519-9940210432020}

\section{Performance of heifers}

Initial and final fasted weights (i.e., feed and water withheld for $16 \mathrm{~h}$ ) were obtained before to start and at the end of each grazing cycle (28 days), and then the weight gain ( $\mathrm{kg}$ animal-1) per grazing cycle was calculated by the difference between final and initial weights. Moreover, the daily weight gain (kg animal-1 day-1) was accounted from the weight gain per cycle divided by twenty-eight days. The supplement intake was obtained subtracting the number of supplements offered during the grazing cycle and leftovers collected at the feeders.

To estimate the forage intake $(\mathrm{kg})$, the titanium dioxide ( $\mathrm{TiO} 2)$ was used as an external indicator and indigestible neutral detergent fiber (NDFi) as an internal indicator. The doses of $\mathrm{TiO} 2$ were encapsulated and administered orally over for 10 days during the grazing cycle. The $\mathrm{TiO}_{2}$ was administered in two daily doses $(3 \mathrm{~g}$ between 06:00 and 07:00h; and $3 \mathrm{~g}$ between 16:00 and 17:00h). In the last three days, at the same time as the $\mathrm{TiO} 2$ supply, approximately $150 \mathrm{~g}$ of feces was collected directly from the rectal cavity. Fecal production was estimated based on the ratio between the amount of the indicator administered into the animal and its concentration in the feces (SMITH and REID, 1955). Fecal production, total dry matter intake (INCT-CA F-009/1) and NDFi were calculated. Based on the dry matter intake, the intake of crude protein ( $\mathrm{g}$ day-1 kg-0.75), ether extract (g day-1), neutral detergent fiber ( $\mathrm{g}$ day-1 \%), and digestibility of dry matter (\%) were calculated.

\section{Statistical analysis}

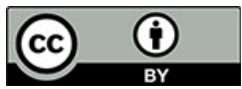

The data were analyzed using the general linear models (GLM procedure) according to $Y \mathrm{ijkl}=\mu+\mathrm{Si}+\operatorname{Res}(\mathrm{a}) \mathrm{ik}+$ $\mathrm{Ej}+\mathrm{SEij}+\mathrm{Res}(\mathrm{b}) \mathrm{ijk}$; in which Yijkl is the independent variable; $\mu=$ overall mean; $\mathrm{Si}=$ fixed effect of supplementation treatments $; \operatorname{Res}(a)=$ error type a (main plot); Ej = fixed effect of seasons; $(\mathrm{SE})$ ij = effect of supplementation treatments into the season; e Res(b)ijk = error type b (subplot). The pair-wise comparison were performed using the $\mathrm{F}$ test, and the significance was declared at $\mathrm{P}<0.05$.

\section{RESULTS AND DISCUSSION}

There was no significant effect ( $P$ $<0.05)$ on the dry matter intake, crude protein, ether extract, neutral detergent fiber, and dry matter digestibility (Table $2)$, between treatments $(\mathrm{P}<0.05)$. However, there was a significant effect ( $\mathrm{P}<0.05)$ between seasons; e.g., respective means of dry matter intake ( $\mathrm{kg} \mathrm{day}^{-1}, \% \mathrm{BW} \mathrm{g} / \mathrm{kg} \mathrm{0.75)}$, intake of crude protein ( $\mathrm{g}$ day $^{-1} \mathrm{~g} / \mathrm{kg} 0.75$ ), ether extract (g day-1), neutral detergent fiber (g day- 1 and\% BW) were 3.95 and 2.88 $\mathrm{kg}, 2.54$ and $1.65 \%, 89.27$ and $59.56 \mathrm{~g}$ $\mathrm{kg}^{0.75}, 429.89$ and $298.43 \mathrm{~g}$ day- $1,9.72$ and $6.18 \mathrm{~g} \mathrm{~kg} 0.75,118.79$ and $84.07 \mathrm{~g}$ day-1, 2.90 and $2.05 \mathrm{~kg}$ day-1, 1.86 and $1.18 \%$, for Spring and Summer seasons. Moreover, the dry matter intake (\% BW and $\mathrm{g} \mathrm{kg} 0.75$ of $\mathrm{DM})$ were higher $(\mathrm{P}<$ 0.05 ) during the spring season (e.g., 2.53 vs $1.64 \% \mathrm{BW}$; and 89.26 vs 59.56 g kg0.75 DM). Similarly, Paciullo et al. (2009) observed dry matter intake of heifers ranging between 2.1 and $2.3 \%$ $\mathrm{BW}$ for drought and rainy seasons, respectively.

\section{Animal Nutrition}


Rev. Bras. Saúde Prod. Anim., Salvador, v.21, 01 - 14, e210432020, 2020 http://dx.doi.org/10.1590/S1519-9940210432020

The reduction of forage consumption between seasons can be explained by the reduction in rainfall from November 2014 to March 2015 (Figure 1). According to Silva-Marques (2015), the forage intake during drought seasons is replaced by the supplement consumption at a maximum of $64 \%$. Also, the substitutive effect occurs only when supplements are provided in an amount greater than $0.2 \% \mathrm{BW}$. Thus, the lower forage consumption caused by the supply of supplements has significant importance for nonequilibrium grazing systems, as such strategies aim to maximize ruminal digestion, consumption and cattle performance kept under low forage availability, as in the experiment local summer.

Table 2. Mean dry matter intake (DMI) of crude protein (CP), ether extract (EEI), neutral detergent fiber (FDNI), and dry matter digestibility (DMD) of heifers across the study period

\begin{tabular}{|c|c|c|c|c|c|c|c|}
\hline \multirow[b]{2}{*}{$\begin{array}{l}\text { Variable/Seaso } \\
\mathrm{n}\end{array}$} & \multicolumn{2}{|c|}{ Treatment } & \multirow[b]{2}{*}{$\mathrm{X}$} & \multicolumn{3}{|c|}{$\mathrm{P}$ value } & \multirow[b]{2}{*}{$\begin{array}{l}\text { CV } \\
(\%)\end{array}$} \\
\hline & SM & SP & & Season & $\begin{array}{c}\text { Treatmen } \\
\mathrm{t}\end{array}$ & $\begin{array}{c}\text { Season } \mathrm{x} \\
\text { Treatmen } \\
\mathrm{t}\end{array}$ & \\
\hline \multicolumn{8}{|l|}{ DMI (kg day $\left.{ }^{-1}\right)$} \\
\hline Spring & $4.02 \mathrm{~A}$ & $3.87 \mathrm{~A}$ & 3.95 & $\begin{array}{c}0.0046 \\
*\end{array}$ & $0.8937^{\mathrm{ns}}$ & $0.7704^{\mathrm{ns}}$ & $\begin{array}{c}28.8 \\
8\end{array}$ \\
\hline Summer & $2.85 \mathrm{~B}$ & $2.90 \mathrm{~B}$ & 2.88 & & & & \\
\hline \multicolumn{8}{|l|}{ DMI (\%BW) } \\
\hline Spring & $2.68 \mathrm{~A}$ & $2.39 \mathrm{~A}$ & 2.54 & $\begin{array}{c}0.0001 \\
*\end{array}$ & $0.3013^{\mathrm{ns}}$ & $0.4533^{\mathrm{ns}}$ & $\begin{array}{c}21.2 \\
6\end{array}$ \\
\hline Summer & $1.67 \mathrm{~B}$ & $1.62 \mathrm{~B}$ & 1.65 & & & & \\
\hline \multicolumn{8}{|l|}{ DMI $\left(\mathrm{g} / \mathrm{kg}^{0,75}\right)$} \\
\hline Spring & $93.54 \mathrm{~A}$ & $84.99 \mathrm{~A}$ & 89.27 & $\begin{array}{l}0.0001 \\
*\end{array}$ & $0.4028^{\mathrm{ns}}$ & $0.5133^{\mathrm{ns}}$ & $\begin{array}{c}21.4 \\
8\end{array}$ \\
\hline Summer & $60.09 \mathrm{~B}$ & $59.03 \mathrm{~B}$ & 59.56 & & & & \\
\hline \multicolumn{8}{|l|}{$\mathrm{CP}(\mathrm{g})$} \\
\hline Spring & $\begin{array}{c}443.17 \\
\text { A }\end{array}$ & $\begin{array}{c}416.61 \\
\text { A }\end{array}$ & $\begin{array}{c}429.8 \\
9\end{array}$ & $\begin{array}{c}0.0015 \\
*\end{array}$ & $0.8900^{\mathrm{ns}}$ & $0.5722^{\mathrm{ns}}$ & $\begin{array}{c}29.0 \\
1\end{array}$ \\
\hline Summer & $\begin{array}{c}290.36 \\
\text { B }\end{array}$ & $\begin{array}{c}306.49 \\
\text { B }\end{array}$ & $\begin{array}{c}298.4 \\
3 \\
\end{array}$ & & & & \\
\hline \multicolumn{8}{|l|}{$\mathrm{CP}\left(\mathrm{g} / \mathrm{kg}^{0,75} \mathrm{~g}\right)$} \\
\hline Spring & $10.30 \mathrm{~A}$ & $9.14 \mathrm{~A}$ & 9.72 & $\begin{array}{c}0.0001 \\
*\end{array}$ & $0.3907^{\mathrm{ns}}$ & $0.3052^{\mathrm{ns}}$ & $\begin{array}{c}21.5 \\
7\end{array}$ \\
\hline Summer & $6.12 \mathrm{~B}$ & $623 \mathrm{~B}$ & 6.18 & & & & \\
\hline \multicolumn{8}{|l|}{ CEE (g) } \\
\hline Spring & $\begin{array}{c}115.12 \\
\mathrm{~A}\end{array}$ & $\begin{array}{c}122.46 \\
\mathrm{~A}\end{array}$ & $\begin{array}{c}118.7 \\
9\end{array}$ & $\begin{array}{l}0.0028 \\
*\end{array}$ & $0.3420^{\mathrm{ns}}$ & $0.7866^{\mathrm{ns}}$ & $\begin{array}{c}29.5 \\
4\end{array}$ \\
\hline Summer & $77.50 \mathrm{~B}$ & $90.64 \mathrm{~B}$ & 84.07 & & & & \\
\hline $\begin{array}{l}\text { NDFI (kg) } \\
\text { Spring }\end{array}$ & $2.94 \mathrm{~A}$ & $2.85 \mathrm{~A}$ & 2.90 & 0.0027 & $0.9200^{\mathrm{ns}}$ & $0.8063^{\mathrm{ns}}$ & 29.0 \\
\hline
\end{tabular}

Animal Nutrition

Received on: 22/11/2018 
Rev. Bras. Saúde Prod. Anim., Salvador, v.21, 01 - 14, e210432020, 2020 http://dx.doi.org/10.1590/S1519-9940210432020

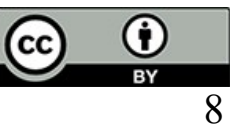

Summer 2.03B $\quad 2.07 \mathrm{~B} \quad 2.05$

\section{NDFI}

$\left(\mathrm{g} / \mathrm{kg}^{0,75} \mathrm{~g}\right)$

Spring

$1.96 \mathrm{~A} \quad 1.76 \mathrm{~A}$

1.86

0.0001
$*$

$0.3240^{\text {ns }}$

$0.4873^{\mathrm{ns}}$

21.3

Summer

1.19B $1.16 \mathrm{~B} \quad 1.18$

DMD (\%)

Spring

Summer

49.76a $46.80 \mathrm{~b}$

A B

48.28

$0.5841^{\mathrm{n}}$

$0.7705^{\text {ns }}$

$0.0002 *$

4.34

$47.00 \mathrm{~b} \quad 50.39 \mathrm{a}$

B A

48.70

Different letters in rows and columns are different $(\mathrm{P}<0.05)$; SM: Mineral salt; SP: Protein salt.

Our findings showed that there was a reduction in the grass biomass near to $25.7 \%$ (Figure 2) between the first and last grazing cycles.

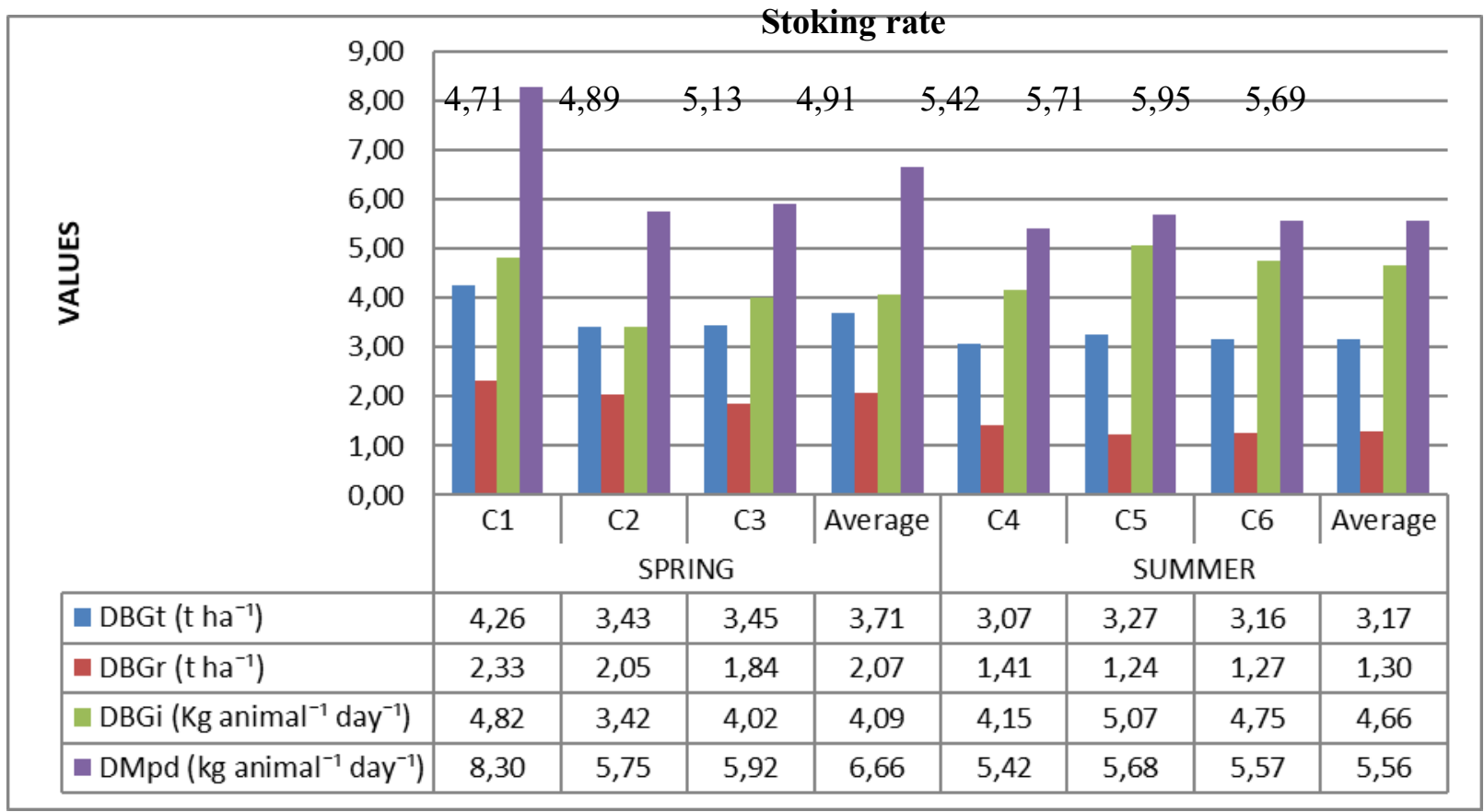

Figure 2. The total Dry Biomass Grass (DBGt), Dry Biomass Grass residue (postgrazing) (DBGr), Dry Biomass Grass intake (DBGi) and, dry matter potentially digestible (DMpd), and stocking rate, according to grazing cycles and seasons.

According to Mertens (1994), the animal performance is a product of the intake of digestible and metabolizable nutrients, once 60 to $90 \%$ of the changes in animal performance are associated with the corresponding changes on consumption, while only 10 to $40 \%$ are ascribed to variations in the digestibility. The dry matter intake can also be influenced by secondary agents

\section{Animal Nutrition}

Received on: 22/11/2018 
such as an indigestible fraction of the NDF and the potential rate of fermentation of the NDF (LANDELL et al., 2002), which can result in a decrease of nutrient intake. Indeed, the consumption of crude protein also decreased during the summer, once they are related to the DMI.

The forage showed a percentage of crude protein within dry matter above to $70 \mathrm{~g} \mathrm{~kg}-1$, by which is considered minimal so that the ruminal microorganisms would have full degradation capacity of the fibrous substrates of the basal forage (LAZZARINI et al., 2009; SAMPAIO et al., 2009) and above $100 \mathrm{~g} \mathrm{~kg}^{-1} \mathrm{DM}$, described as minimal by Detmann et al. (2010). Thus, it is possible to see that the supplementation supply contributes significantly to better pasture use, especially in tropical regions, where pasture is the main source of food.

The dry matter digestibility was higher $(\mathrm{P}<0.05)$ during the summer. We observed the respective values ranging from 46.80 to $50.59 \%$ for heifers that were supplemented with protein salt, while 49.76 and $47.00 \%$ to those with mineral salt for spring and summer. The improvement of digestibility observed in animals supplemented with protein salt can be ascribed to the urea content, once the supplementation of non-protein nitrogen (NNP) increases the fiber degradation in neutral detergent due to the better physical-chemical environment for the fermentation processes in the rumen and the possible absence of inhibitory relationships between microbial species.
Costa et al. (2015) revealed that the additional nitrogen (N) supply to animals consuming low-quality tropical grass favored the growth of fibrinolytic bacteria, increased the rate of digestion and microbial protein synthesis and, consequently, the voluntary consumption, improving the energy balance from fibrous carbohydrates (CF) of forage. Increasing the use of the energy substrates of the supplement results in a greater nutrients supply to the intestine and volatile fatty acids for energy metabolism.

The average of NDF is shown in Table 2. Surprisingly, there were no differences $(\mathrm{P}>0.05)$ for NDF across the grazing cycles in which do not agree with the hypothesis that the as much as the fiber content in a given food, the slower will be the food degradation and ruminal emptying. This indicates that when pastures are properly managed, they can produce forage with good chemical composition and that the main determinant of performance will be the forage consumption (MUNIZ \& PRADO 2011).

Table 3 shows the average values of average daily weight gain of heifers supplemented with protein and mineralized salt. We observed that the type of supplement and seasons did not change $(\mathrm{P}>0.05)$ the daily weight gain. Flores et al (2008) reported that crossbred steers in B. Brizantha cv. Marandu gains of $471 \mathrm{~g} /$ day, with a stocking rate of $3.5 \mathrm{UA}$ ha during the summer and autumn.

\section{Animal Nutrition}


Table 3. Mean daily gain (MDG) of heifers across the study period

\begin{tabular}{|c|c|c|c|c|c|c|c|}
\hline \multirow[b]{2}{*}{ Variable } & \multicolumn{2}{|c|}{ Treatment } & & \multicolumn{3}{|c|}{$\mathrm{P}$ value } & \multirow{2}{*}{$\begin{array}{l}\text { CV } \\
(\%)\end{array}$} \\
\hline & MS & PS & $X$ & Season & Treatment & $\begin{array}{l}\text { Season } \mathrm{x} \\
\text { Treatment }\end{array}$ & \\
\hline $\begin{array}{l}\text { MDG } \\
\text { (g/day) } \\
\text { Spring }\end{array}$ & 323.31 & 344.63 & 333.97 & $0.8064^{\mathrm{ns}}$ & $0.1586^{\mathrm{ns}}$ & $0.3806^{\mathrm{ns}}$ & 53.50 \\
\hline Summer & 278.94 & 369.64 & 324.29 & - & - & - & - \\
\hline$X$ & 301.13 & 357.14 & - & - & - & - & - \\
\hline
\end{tabular}

SM: Mineral salt; SP: Protein salt; X- treatment averages.

We believe that inadequate management during the growth and weaning phase can impact on animal's performance. Therefore, it seems that the mineral supplementation to attend the growing animal's requirements, associated with good pasture management during the wet seasons is suitable strategies to provide satisfactory nutritional requirements for this phase. Moreover, we highlight the potential $B$. Brizantha cv. Marandu which to attend the requirement for good animal performance during the dry season, when normally animals have the potential to lose weight.

Table 4 shows the supplements intake, protein salt and mineral salt, which the average was 65.5 and $36.5 \mathrm{~g} 100 \mathrm{~kg}$ of $\mathrm{BW}$, respectively. This result is expected due to the differences in nutrient content and levels of common salt, which is the main limiting factor in the mineral supplement intake.

Table 4. Mineral supplements intake by heifers across the study period

\begin{tabular}{lcccccc}
\hline \multirow{2}{*}{ Variable/Season } & \multicolumn{2}{c}{ Treatment } & \multicolumn{3}{c}{ P value } & \multirow{2}{*}{ CV (\%) } \\
\cline { 2 - 5 } & MS & PS & Season & Treatment & $\begin{array}{c}\text { Season } x \\
\text { Treatment }\end{array}$ & \\
\hline Spring & & & & & \\
Summer & $39.00 \mathrm{~B}$ & $71.00 \mathrm{~A}$ & $0,1722^{\mathrm{ns}}$ & $0.0006^{*}$ & $0.5600^{\mathrm{ns}}$ & 18.03 \\
$\mathrm{n}$ & $34.00 \mathrm{~B}$ & $60.00 \mathrm{~A}$ & & & \\
$\mathrm{X}$ & 36.5 & 65.5 & & & & \\
\hline
\end{tabular}

Different letters in rows and columns are different $(\mathrm{P}<0.05)$; MS: Mineral salt; PS: Protein salt; $\mathrm{X}$ - treatment averages

According to Signoretti (2011), once the heifers during the stocker phase represent a high cost in milk production systems, the use of a lower supplementation level coupled with adequate pasture management can be used as a nutritional management strategy, without considerable delays to start their reproductive life. Our data shows that the animals that received protein salt obtained better feed conversion (9.54), with an average gain of $104.70 \mathrm{~g} \mathrm{~kg}-1$ DM ingested, while those supplemented with mineral salt had a feed conversion of 11.41 and a gain of $87.59 \mathrm{~g} \mathrm{kg-1}$ of DM. The

\section{Animal Nutrition}


observed feed efficiency (Table 5) was better in the summer $(0.13)$ than in the spring (0.8). In the spring the forage support was higher, and then an inverse relationship between forage supply and feed efficiency. According to Muniz and Prado (2011), a high feed conversion (generating high performance) is associated with high consumption of dry matter, which, in turn, is resultant of a high supply of forage.

Table 5. Mean of dry matter intake (DMI), supplement consumption (CS), mean daily gain (MDG) and feed efficiency (FE) of heifers across the study period.

\begin{tabular}{lcccccc}
\hline & \multicolumn{5}{c}{ Treatment } \\
\cline { 2 - 7 } Variable/Season & \multicolumn{3}{c}{ Mineral salt } & Protein salt \\
\cline { 2 - 7 } & Spring & Summer & Mean & Spring & Summer & Mean \\
\hline kg day $\left.^{-1}\right)$ & 4.02 & 2.85 & 3.43 & 3.87 & 2.90 & 3.38 \\
SC $\left(\right.$ g day $\left.^{-1}\right)$ & 58.50 & 58.02 & 58.26 & 114.96 & 107.41 & 111.18 \\
MDG $\left(\right.$ g day $\left.^{-1}\right)$ & 323.31 & 278.94 & 301.12 & 344.63 & 369.64 & 357.13 \\
FE & 0.08 & 0.13 & 0.11 & 0.09 & 0.13 & 0.11 \\
\hline
\end{tabular}

SC: Supplement consumption

Table 6 shows the economic data of the supplementation (R\$). The data considers February 2016 in the Paraiba state, Brazil. Even though the daily weight gain did not differ between treatments, heifers that received protein salt had superior digestibility of dry matter, leading to a trend of weight gain at an order of close to $15 \%$.

Table 6. Running costs ( $\mathrm{R} \$$ ) of the two experimental treatments

\begin{tabular}{|c|c|c|}
\hline \multirow[t]{2}{*}{ Variable } & \multicolumn{2}{|c|}{ Treatment } \\
\hline & Mineral salt & Protein salt \\
\hline Supplement cost $\left(\mathrm{R} \$ / \mathrm{kg}^{*}\right)$ & 1.83 & 1.50 \\
\hline Intake $\left(\mathrm{kg}\right.$ animal $\left.{ }^{-1} \mathrm{day}^{-1}\right)$ & 0.059 & 0.112 \\
\hline Daily weight gain (kg) & 0.301 & 0.357 \\
\hline Cost $\left(\mathrm{R} \$\right.$ animal day $\left.^{-1}\right)$ & 0.108 & 0.168 \\
\hline Cost/kg daily weight gain ( $\mathrm{R} \$$ ) & 0.36 & 0.47 \\
\hline
\end{tabular}

*Product cost for February 2016.

Therefore, when analyzing exclusively the relationship between the cost of supplementation treatments and the daily weight gain, we would conclude that this is not economically profitable for the stocker phase-in periods of high forage support. The heifers that were supplemented with mineral salt presented better results considering only the supplement costs, observing that the different impacts in a reduction of three months of age at first delivery, requiring that biological criteria should be accounted for making the decision.

In many Livestock systems, the lack of immediate farm income has relegated low-quality marginal pastures to the heifers during the stocker phase, resulting in reduced performance and productivity rates. Then, the pasture production intensification with supplementation becomes a profitable 
option to improve the performance of heifers during the stocker phase, which has a direct impact on the entire dairy system. The effect of the supplements used here in this study (protein salt and mineral salt) were equivalent. The daily weight gain was low for the management level used, requiring a better adjustment of the stocking rate, as it may have affected the forage consumption.

\section{ACKNOWLEDGMENTS}

This study was funded by the Dairy Milk Experimental Unit 's resources, 2013.

\section{REFERENCES}

BRAGA, G.J.; PEDREIRA, C.G.S.; HERLING, V.R.; LUZ, P.H.C.

Eficiência de pastejo de capim Marandu submetido a diferentes ofertas de forragem. Pesquisa Agropecuária Brasileira, v.42, p.1641-1649, 2007. DOI:10.1590/S0100204X2007001100017

COSTA, N.L.; MONTEIRO, A.L.G.; SILVA, A.L.P; MORAES, A.; GIOSTRI, A.F.; STIVARI, T.S.S.; GILAVERTE, S.; BALDISSERA, T.C.; PIN, E.A. Considerações sobre a degradação da fibra em forragens tropicais associada com suplementos energéticos ou nitrogenados. Archivos de Zootecnia. 64 (R): 31-41. 2015. DOI: 10.21071/az.v64i247.504

COSTA, N.L.; PAULINO, V. T.; TOWNSEND, C. R.; MAGALHÃES, J. A.; OLIVEIRA, J. R. da C.

Desempenho agronômico de genótipos de Brachiaria brizantha em diferentes idades de corte em Porto Velho, Rondônia, Brasil. REDVET. Revista
Electrónica de Veterinaria, v.8, n.8, p.1-5, 2007.

DA SILVA, S.C.; NASCIMENTO JR., D. Avanços na pesquisa com plantas forrageiras tropicais em pastagens: características morfofisiológicas e manejo do pastejo. Revista Brasileira de Zootecnia, v.36, suplemento especial, p.121-138, 2007.

DOI:10.1590/S151635982007001000014.

DA SILVA, T.C.; PERAZZO, A.F.; MACEDO, C.H.O.; BATISTA, E.D.; PINHO, R.M.A.; BEZERRA, H.F.C.; SANTOS, E.M. Morfogênese e estrutura de Brachiaria decumbens Em resposta ao corte e adubação nitrogenada. Archivos de Zootecnia 61(233): 91-102. 2012

DETMANN, E.; SOUZA, M. A.; VALADARES FILHO, S. C. Métodos para análise de alimentos. Visconde do Rio Branco, MG: Suprema, p.214, 2012.

DETMANN, E.; PAULINO, M.F.; ZERVOUDAKIS, J.T.; VALADARES FILHO, S. C.; LANA, R. P.; QUEIROZ, D. S. Suplementação de novilhos mestiços durante a época das águas: parâmetros ingestivos e digestivos. Revista Brasileira de Zootecnia, v.30, p.1340-1349, 2001. DOI:10.1590/S151635982001000500030

DIAS-FILHO, M.B., Diagnóstico das Pastagens do Brasil. Belém: Embrapa Amazônia Oriental, 2014. 36p.

(Documento 402).

DIFANTE, G. S.; NASCIMENTO JR, D.; SILVA, S. C.; EUCLIDES, V. P. 
B.; MONTAGNER, D. B.; SILVEIRA, M. C. T.; PENA, K. S. Características morfogênicas e estruturais do capimmarandu submetido a combinações de alturas e intervalos de corte. Revista Brasileira de Zootecnia, v.40, n.5, p.955-963, 2011. DOI:10.1590/S151635982011000500003

DOMINGUES, F.N.;SILVA, J.F.C.; VÁSQUEZ, H.M.; VIEIRA, R.A.M.; FEROLLA, F.S.; LISTA, F.N.

Desempenho ponderal de novilhas mestiças Holandês $\times$ Zebu submetidas a duas estratégias de suplementação mineral. Revista Brasileira de

Zootecnia, v.37, n.2, p.343-349, 2008. DOI:10.1590/S151635982008000200022

FARIAS, M. S.; PRADO, I. N.; VALERO, M. V.; ZAWADZKI, F.; SILVA, R. R.; EIRAS, C. E.; RIVAROLI, D. C.; LIMA, B. S. Níveis de glicerina para novilhas suplementadas em pastagens: desempenho, ingestão, eficiência alimentar e digestibilidade. Semina: Ciências Agrárias, v. 33, n. 3, 2012, p. 1177-1187. DOI: $10.5433 / 1679-$ 0359.2012v33n3p1177

FLORES, R.S.; EUCLIDES, V. P. B.; ABRÃO, M. P. C.; GALBEIRO, S.; DIFANTE, G. S.; BARBOSA, R. A. Desempenho animal, produção de forragem e características estruturais dos capins Marandu e Xaraés submetidos a intensidades de pastejo. Revista Brasileira de Zootecnia, v.37, n.8, p.1355-1365, 2008.

DOI.:10.1590/S151635982008000800004

LANDELL, M.G.A.; CAMPANA, M. P.; RODRIGUES, A. A. de; CRUZ, G.
M. da; BATISTA, L. A. R.; FIGUEIREDO, P. ; SILVA, M. A. de; BIDOIA, M. A. P.; ROSSETTO, R. ; MARTINS, A. L. M.; GALLO, P. B.; KANTHACK, R. A. D.; CAVICHIOLI, J. C.; VASCONCELOS, A. C. M. de; XAVIER, M. A. A variedade IAC862480 como nova opção de cana-deacuçar para fins forrageiros: manejo de produção e uso na alimentação animal. IAC. Boletim Técnico, v. 1,93p. 2002.

LAZZARINI, I.; DETMANN, E.; SAMPAIO, C.B.; PALIULINO, M. F.; VALADARES FILHO, S. C.; SOUZA, M. A.; OLIVEIRA, F. A. Dinâmica de trânsito e degradação da fibra em detergente neutro em bovinos alimentados com forragem tropical de baixa qualidade e compostos nitrogenados. Arquivo Brasileiro de Medicina veterinária e Zootecnia, v.61, p.635-647, 2009.

DOI:10.1590/S151635982009001000024

LEITE, T. S.; LEITE, M.S.; TORRES, S. B. Palma forrageira: situação atual e perspectivas para o cultivo na região semiárida do Ceará, Brasil. Arquivos de Ciências Veterinárias e Zoologia. UNIPAR, Umuarama, v. 21, n. 2, p. 77 83, abr./jun. 2018. DOI:

10.25110/arqvet.v21i2.2018.6310

MERTENS, D.R. Regulation of forage intake. In: FAHEY, G.C.Jr.; COLLINS, M.; MERTENS, D.R.; MOSER, L.E. (Ed.). Forage quality evaluation and utilization. Madison: American Society of Agronomy, Crop Science of America; Soil Science of America, 1994. $988 \mathrm{p}$.

MUNIZ, D. M. S.; PRADO, T. A. A eficiência do manejo do capim-marandu 
Rev. Bras. Saúde Prod. Anim., Salvador, v.21, 01 - 14, e210432020, 2020 http://dx.doi.org/10.1590/S1519-9940210432020

voltada à produção animal. Cadernos de pós-graduação da FAZU, v. 2, 2011.

NATIONAL RESEARCH COUNCIL (Washington, EUA). Nutrient requeriments of beef cattle. 6 th.

Washington, D.C., 1996. 242p.

NATIONAL RESEARCH COUNCIL. Nutrient requirements of dairy cattle. 7th. Washington: National Academy Press, 2001. 381p.

PACIULLO, D.S.C.; LOPES, F.C.F.; MALAQUIAS JR, J.D.; VIANA FILHO, A.; RODRIGUEZ, N.M.; MORENS, M.J.F.; AROEIRA, L.J.M. Características do pasto e desempenho de novilhas em sistema silvopastoril e pastagem de braquiária em monocultivo. Pesquisa Agropecuária Brasileira. v. 44, n. 11, p 1528-1535; 2009. DOI:10.1590/S0100204X2009001100022

PAULINO, M.F.; DETMANN, E.; VALENTE, E.E.L. et al. Nutrição de bovinos em pastejo. In: SIMPÓSIO INTERNACIONAL SOBRE PRODUÇÃO ANIMAL EM PASTEJO, 2.: DZO/UFV, 2008. p.131169.

PERES, A.A.C.; SANTOS, A.A.; CARVALHO, C.A.B. E

BRANDALISE, N. Análise financeira de sistemas de produção para novilhas em pastagem de Brachiaria brizantha 'Xaraés' suplementadas com mistura mineral. Archivos de Zootecnia. v. 64, n. 246, p 123-130; 2015. DOI:10.21071/az.v64i246.386

REIS, R.P.; MEDEIROS, A.L.; MONTEIRO, L.A. Custo de produção na atividade leiteira na região sul de Minas Gerais. Organizações Rurais \& Agroindústriais, v.3, n. 2, 2011. DOI: 10.22004/ag.econ.43379

SALES, E.C.J.; MONÇÃO, F. P.; PEREIRA, D. A.; MOTA, V.A. C.; REIS, S. T.; PIRES, D. A. A.; ALVES, D. D.; SAMPAIO, J. P. R. Avaliação da produção de capim-Marandu sob doses de nitrogênio em duas alturas de resíduos pós corte. Revista Unimontes Científica, v.15, p.42-54, 2013.

SAMPAIO, C.B.; DETMANN, E.; LAZZARINI, I. et al. Rumen dynamics of neutral detergent fiber in cattle fed low-quality tropical forage and supplemented with nitrogenous compounds. Revista Brasileira de Zootecnia, v.38, p.560-569, 2009. DOI:10.1590/S151635982009000300023

SIGNORETTI, R.D. Desempenho e comportamento ingestivo de novilhas leiteiras em pastejo submetidas à frequência e níveis de suplementação. Boletim de Indústria Animal, v.69, n.2, p.147-154, 2012.

SIGNORETTI, R.D. Estratégias de suplementação da dieta de novilhas leiteiras mantidas a pasto na época da seca. Revista Pesquisa \& Tecnologia. v. 8, n. $86,2011$.

DOI:10.17523/bia.v70n1p28

SILVA-MARQUES, R. P.; ZERVOUDAKIS, J. T.; HATAMOTOZERVOUDAKIS, L. K.; CABRAL, L. S.; ALEXANDRINO, E.; JOSÉ NETO, A.; SOARES, J. Q.; MELO, A. C. B.

Semina: Ciências Agrárias, v. 36, n. 1, p. 509-524. 2015. DOI: 10.5433/16790359.2015v36n1p509 
SILVA, D.J.; QUEIROZ, A.C. Análise de alimentos:métodos químicos e biológicos. 3.ed. Viçosa: Universidade Federal de Viçosa, 2002. 235p.

SMITH, A.M.; REID, J.T. Use of chromic of as an indicator of fecal output for the purpose of determining the intake of a posture herbage by grazing cows. Journal of Dairy Science, v.38, n.5, p.515-524, 1955.

DOI : $10.3168 /$ jds.S00220302(55)95006-2

VAN SOEST, P.J. Nutritional ecology of the ruminant. 2th. Ithaca: Cornell University Press, 1994. 476p. 